\title{
References
}

Berthelsen, A. \& Noe-Nygaard, A. 1965: The Precambrian of Greenland. In Rankama, K. (editor) The Precambrian, 2, 113-262. New York \& London: Interscience.

Larsen, O. \& Møller, J. 1968: K/Ar age determinations from western Greenland 1. Reconnaissance programme. Rapp. Gronlands geol. Unders. 15, 82-86.

Windley, B. F., Henriksen, N., Higgins, A. K., Bondesen, E. and Jensen, S. B. 1966: Some border relations between supracrustal and infracrustal rocks in South-West Greenland. Rapp. Gronlands geol. Unders. 9, 43 pp.

\section{ROUTINE K/AR AGE DETERMINATIONS ON ROCKS FROM GREENLAND CARRIED OUT FOR GGU IN 1970}

\section{Bridgwater}

The programme of commercial age determinations started in 1969 (Bridgwater, 1970) was continued to supplement the work carried out by the University of Copenhagen (Larsen, this report). The material dated represents a rather heterogeneous collection of rocks from many parts of Greenland about which information was required for current geological work but which were not included in existing age determination projects. All the results obtained are listed whether or not the "ages". have a clear geological significance, since a major reason for carrying out this form of reconnaissance survey is to test the suitability of $\mathrm{K} / \mathrm{Ar}$ methods for making more detailed studies. Full analytical data is available on request from GGU. Unless otherwise stated the results given are means of three determinations. The constants used are:

$$
\begin{aligned}
& \lambda_{\mathrm{e}}=0.584 \times 10^{-10} \mathrm{yr}^{-1} \\
& \lambda_{\beta}=4.72 \times 10^{-10} \mathrm{yr}^{-1}
\end{aligned}
$$

The references given are those to the most relevant publications. In the case of rocks of which there are no published accounts, the name given is that of the collector.

\section{North Greenland}

The geological background for the samples listed here is to be found in Dawes \& Soper (1970 and this report) and Dawes (1971). The geographical coordinates used are from the U.S.A.F. World Aeronautical Chart 1:1000 000, 5th edition. 
32.3 土 $3.2 \mathrm{~m}$. y. whole rock

GGU 53452. An intermediate or acid volcanic rock with, apparently, a strong cataclastic texture from the Kap Washington Volcanic Group, northern Peary Land. $83^{\circ} 29^{\prime} \mathrm{N}, 38^{\circ} 35^{\prime} \mathrm{W}$.

Dawes \& Soper (1970)

$34.9 \pm 3.5 \mathrm{~m}$. y. whole rock

GGU 53443. An acid volcanic rock from the Kap Washington Volcanic Group, northern Peary Land. $83^{\circ} 30^{\prime} \mathrm{N}, 38^{\circ} 53^{\prime} \mathrm{W}$.

Dawes \& Soper (1970)

A rock with slightly less apparent cataclastic texture than 53452 . This sample appears to have once formed part of a rhyolitic suite.

\section{$42.3 \pm 4.2 \mathrm{~m}$. y. muscovite}

GGU 53427. A muscovite-biotite schist, Kap Christian IV, northern Peary Land. $83^{\circ} 36^{\prime} \mathrm{N}, 36^{\circ} 00^{\prime} \mathrm{W}$.

Dawes \& Soper (1970)

A feldspathic mica schist (muscovite, biotite, quartz, feldspar, with accessory oxides, apatite and zircon). The feldspars and micas show slight alteration

\section{$47.1 \pm 2.4 \mathrm{~m}$. y. whole rock}

GGU 100624. Chloritoid-muscovite schist, northern Peary Land. $83^{\circ} 29 \mathrm{~N}, 37^{\circ} 03^{\prime} \mathrm{W}$.

Dawes \& Soper (1970)

A fresh chloritoid-muscovite schist with a little quartz in the fine-grained micaceous groundmass.

\section{$66.0 \pm 6.6 \mathrm{~m}$. y. whole rock}

GGU 53487. Alkali olivine dolerite trending approximately $\mathrm{E}-\mathrm{W}$, south side of O. B. Bøggild Fjord, northern Peary Land. $83^{\circ} 01^{\prime}$ N, $39^{\circ} 26^{\prime}$ W. Dawes \& Soper (1970) The $\mathrm{K} / \mathrm{Ar}$ age is taken to be close to that of the original intrusion of the dyke.

$$
75.9 \text { 土 } 3.6 \mathrm{~m} \text {. y. biotite }
$$

GGU 53422. Muscovite-biotite schist, $10 \mathrm{~km}$ south-west of Kap Morris Jesup, northern Peary Land. $83^{\circ} 33^{\prime} \mathrm{N}, 34^{\circ} 15^{\prime} \mathrm{W}$.

Dawes \& Soper (1970)

A fresh microfolded calcareous quartz-muscovite-biotite-calcite-bearing metasediment with accessory feldspar, oxides, apatite and zircon.

\section{$84.2 \pm 4.2 \mathrm{~m} . \mathrm{y}$.}

GGU 53441. Staurolite-garnet-biotite-muscovite schist, northern Peary Land. $83^{\circ} 36^{\prime} \mathrm{N}, 36^{\circ} 10^{\prime} \mathrm{W}$.

Dawes \& Soper (1970)

A fresh staurolite-andalusite-cordierite-muscovite-biotite-schist with some garnet and sillimanite representing one of the highest grade rocks in northern Peary Land.

The Cretaceous and Tertiary ages obtained from the metamorphic rocks of North Greenland show that this area must have passed through one or more regional thermal 
events during the younger Phanerozoic, a fact which was not known with any certainty before the present series of samples were dated.

West Greenland

$$
584 \pm 18 \mathrm{~m} \text {. y. phlogopitic mica }
$$

GGU 120668. Kimberlite dyke trending approximately ENE. $66^{\circ} 32^{\prime} \mathrm{N}, 51^{\circ} 17^{\prime} \mathrm{W}$.

Escher et al. (1970)

A kimberlitic dyke with rounded olivine and phlogopitic mica phenocrysts set in a matrix of olivine, mica, oxides and calcite. The olivines are slightly altered.

This is believed to be a primary feature. The age determinations were carried out on separated phlogopite phenocrysts. There are no geological grounds for suggesting that the age obtained is not the age of intrusion of the kimberlite (cf. GGU 72502 in Bridgwater 1970, and GGU 24496 in Larsen \& Møller, 1968) and the dykes could then be regarded as part of the widespread North Atlantic carbonatitic activity around $600 \mathrm{~m}$. y. ago. However recent $\mathrm{Rb} / \mathrm{Sr}$ studies on a whole rock sample and mica separate from the kimberlite dyke 72502 which was dated as $609 \mathrm{~m}$. y. by the $\mathrm{K} / \mathrm{Ar}$ whole rock method, indicated that this dyke is only a little over $200 \mathrm{~m}$. y. old (Andrews \& Emeleus, 1971). Furthermore, kimberlites in Siberia which have a $\mathrm{K} / \mathrm{Ar}$ age of about $600 \mathrm{~m}$. y. are known to have been intruded much more recently (Sarsadskikh et al., 1966). Further isotopic investigations of the Greenlandic kimberlites are under way.

$$
1869 \pm 150 \mathrm{~m} \text {. y. biotite }
$$

GGU 83208. Rapakivi type hypersthene-biotite granite, from the main Prøven massive. $72^{\circ} 23^{\prime} \mathrm{N}, 55^{\circ} 32^{\prime} \mathrm{W}$. Upernavik district.

Escher \& Pulvertaft (1968)

A biotite-hypersthene-plagioclase-K-feldspar rock with accessory oxide, apatite and zircon. The rock shows a slight foliation and there is some secondary alteration with the formation of small amounts of muscovite, calcite, and chloritic material.

The Prøven granite is one of the youngest plutonic rocks from this part of Greenland. The age obtained is considered to be that of the slight alteration seen in the rock.

$$
\begin{aligned}
& 2010 \pm 80 \mathrm{~m} . \text { y. plagioclase ( } 2 \text { determinations) } \\
& 2649 \pm 106 \mathrm{~m} . \text { y. plagioclase (1 determination) }
\end{aligned}
$$

GGU 121850. Cataclastic hornblende-orthopyroxene-plagioclase-magnetite-quartz gneiss. $67^{\circ} 11^{\prime} \mathrm{N}, 51^{\circ} 07^{\prime} \mathrm{W}$.

Escher et al. (1970)

A gneiss from the southern limit of the granulite facies rocks within the Nagssugtoqidian deformed belt. This rock has been completely recrystallised by Nagssugtoqidian deformation during which the high-grade mineral assemblage was stable. In section the rock is seen to have been partially affected by a cataclastic event after the granulite facies metamorphism with local recrystallisation of the feldspars. The 
large difference in $\mathrm{K} / \mathrm{Ar}$ feldspar ages obtained from this sample means that the figures quoted cannot be used to "date", any particular event. Assuming that excess argon is not present it appears that the main Nagssugtoqidian deformation in this area was earlier than $2000 \mathrm{~m}$. y. ago.

\section{$2173 \pm 43$ m. y. biotite}

GGU 128368. Rapakivi-like granite cutting Archaean gneisses. $66^{\circ} 11^{\prime} \mathrm{N}, 51^{\circ} 07^{\prime} \mathrm{W}$.

Escher et al. (1970)

A hornblende-biotite granite with local hypersthene-bearing units intruding the Archaean gneisses to the south of the Nagssugtoqidian deformed zone. These granites are cut by several series of basic dykes including dykes thought to be similar in age to GGU 44720 (see p. 56). In section the sample showed a mildly cataclastic texture, with hornblende, biotite, magnetite, plagioclase, K-feldspar, quartz, apatite and zircon. The biotite showed some signs of recrystallisation and the feldspar and hornblende both show strain effects. The $\mathrm{K} / \mathrm{Ar}$ age is regarded as that of the cataclastic event affecting the rock.

$$
3257 \pm 130 \mathrm{~m} \text {. y. plagioclase }
$$

GGU 120601. Enderbitic gneiss. $66^{\circ} 48^{\prime} \mathrm{N}, 50^{\circ} 08^{\prime} \mathrm{W}$.

Escher et al. (1970)

An orthopyroxene-plagioclase-quartz gneiss with clear cataclastic effects seen in thin section. Gneisses of this general type are regarded as some of the oldest rocks present in the Archaean block of West Greenland and the K/Ar age given by this sample is close to the age at which the main metamorphic minerals are thought to have formed. However at present it appears that the cataclastic event which affected these rocks (see also GGU 128368 above) is a regional phenomenon related to Nagssugtoqidian deformation to the north, and the high K/Ar age given by this rock is therefore regarded as due to the presence of excess argon. Conventional $\mathrm{K} / \mathrm{Ar}$ age determinations have not given a clear picture of events on the border of the Nagssugtoqidian front and a more sophisticated programme of isotopic age determination is now under way.

$$
3595 \pm 72 \mathrm{~m} . \text { y. biotite }
$$

10309 EV/67 Kryolitselskabet Øresund, Copenhagen. A granodioritic biotite gneiss. $65^{\circ} 12^{\prime} \mathrm{N}, 49^{\circ} 47^{\prime} \mathrm{W}$.

Keto (1970)

A biotite gneiss originally forming the basement to the Isua iron formation with which this rock is now intercalated. The gneiss shows a cataclastic texture and slight alteration of the feldspar suggesting that it was recrystallised during the metamorphism of the Isua supracrustal rocks. A K/Ar determination on hornblende from a metamorphosed sill in the Isua succession (Lambert \& Simons, 1969) gave an age of $1940 \mathrm{~m}$. y., which would suggest that the abnormally high biotite age from the underlying gneisses may reflect the presence of considerable excess argon (compare the biotite dated by Wanless et al. 1970, sample no. 8, tables 1 and 3). 
$2787 \pm 111 \mathrm{~m}$. y. whole rock

GGU 44270 . Basic dyke with primary hornblende, Akuliaruseq. $65^{\circ} 40^{\prime} \mathrm{N}, 52^{\circ} 50^{\prime} \mathrm{W}$.

Windley (1970)

Marginal basic part of a dyke with a hornblende-plagioclase-biotite-Fe oxide mineral assemblage partially replacing an earlier pyroxene-plagioclase rock. This alteration is interpreted as original (Windley, 1970) having been formed during the emplacement of the dyke in active shear zones. The $\mathrm{K} / \mathrm{Ar}$ age is similar to that obtained from GGU 87779 from the centre of a similar dyke in the same swarm (Bridgwater, 1970). This suggests that the age obtained is close to the age of emplacement of the bodies. However K/Ar age determinations on basic rocks emplaced under regional metamorphic conditions is complicated by the possibility of argon over-pressure due to the escape of argon into the dyke magma at the time of emplacement. Further work on these bodies is under way.

\section{$2428 \pm 97 \mathrm{~m}$. y. whole rock}

GGU 125959. Chilled margin of a $25 \mathrm{~m}$ ENE-trending dyke from Portussup nûna, Fiskenæsset. $63^{\circ} 10^{\prime} \mathrm{N}, 50^{\circ} 25^{\prime} \mathrm{W}$.

G. Henderson 1969

A fresh microporphyritic olivine dolerite belonging to the earliest of the two main dyke generations in the area. In contrast to the dykes from the Frederikshåb area which contain considerable excess argon (presumably introduced during Ketilidian metamorphism) this rock is thought to give a reasonable age for the intrusion of the dykes.

South-East Greenland

(see Andrews et al. this report; Bridgwater \& Gormsen, 1969)

$1473 \pm 30 \mathrm{~m}$. y. whole rock ( 2 determinations)

GGU 99499. N-S tholeiitic olivine dolerite dyke, south coast of island on south side of Tingmiarmiut fjord. $62^{\circ} 37^{\prime} 40^{\prime \prime} \mathrm{N}, 42^{\circ} 40^{\prime} \mathrm{W}$. Bridgwater \& Gormsen (1969)

An undeformed moderately fresh tholeiitic olivine dolerite about $10 \mathrm{~m}$ wide cutting: 1) an appinitic sill (see GGU 99495, p. 00) and 2) a metadolerite (GGU 99497, Bridgwater, 1970). The primary minerals include olivine, clinopyroxene, Fe-Ti oxides, plagioclase, apatite, alkali feldspar, biotite and quartz. Some of the feldspars show slight alteration close to interstitial quartz and alkali feldspar. This alteration is regarded as deuteric. No significant argon loss is thought likely although it is just possible that the dyke has been slightly affected by the youngest thermal effects of the Ketilidian metamorphism seen farther south (see sample 224/32 etc. below). There are no geological grounds to suspect the introduction of excess argon. The K/Ar age given by this sample is taken to be close to that of the intrusion of the dyke. Dykes trending approximately N-S intruded after the end of regional metamorphism in the area but before the major E-W Gardar dykes swarms are common in South-East Greenland from Kap Farvel to Angmagssalik. 
$1664 \pm 34 \mathrm{~m}$. y. whole rock ( 2 determinations)

GGU 99362. NNW-SSE trending olivine dolerite, Finnsbu. $63^{\circ} 22^{\prime} 40^{\prime \prime} \mathrm{N}, 41^{\circ} 18^{\prime} \mathrm{W}$.

Bridgwater \& Gormsen (1969)

An almost completely fresh $5 \mathrm{~m}$ wide vertical alkali olivine dolerite trending $160^{\circ}$, $10 \mathrm{~cm}$ from contact. This dyke cuts E-W, presumed pre- $2000 \mathrm{~m}$. y. old dykes in Archaean gneisses and is thought to belong to the same general period of Proterozoic dyke injection as GGU 99499 above. The difference in age and the more alkali nature of this particular dyke compared to GGU 99499 suggest that the approximately N-S dyke swarm in South-East Greenland may comprise several different generations.

$$
1551 \pm 31 \mathrm{~m} . \mathrm{y} \text {. biotite }
$$

224/32. Medium-grained biotite-hornblende gneiss, north side of Ikermît island. $62^{\circ} 16^{\prime} \mathrm{N}, 42^{\circ} 03^{\prime} \mathrm{W}$.

R. Bøgvad, 1932

A biotite-hornblende gneiss presumed to have been formed from Archaean rocks but clearly overprinted by younger metamorphism. The sample was taken close to a large diorite-appinite intrusion which occupies most of Ikermît island. This body is itself slightly recrystallised and it appears that the $\mathrm{K} / \mathrm{Ar}$ age given by the present sample is that of uplift following a regional metamorphic event representing the northernmost effects of the Ketilidian mobile belt.

\section{$1563 \pm 31 \mathrm{~m} . \mathrm{y}$. biotite}

36/32. Hornblende-biotite gneiss, Qutlît. $61^{\circ} 31^{\prime} \mathrm{N}, 42^{\circ} 08^{\prime} \mathrm{W}$. R. Bøgvad, 1932

A hornblende-biotite gneiss presumed to be of Archaean age but clearly recrystallised during a Ketilidian thermal event.

$$
1582 \pm 32 \mathrm{~m} . \mathrm{y} \text {. biotite }
$$

272/32. Biotite-hornblende granite belonging to a deformed appinitic suite of rocks, northern point of small island in Isortoq fjord. $61^{\circ} 29^{\prime} \mathrm{N}, 42^{\circ} 24^{\prime} \mathrm{W}$. R. Bøgvad, 1932

A slightly metasomatised biotite-hornblende granite which has passed through one or more periods of post-crystallisation stress and metamorphism. The $\mathrm{K} / \mathrm{Ar}$ date is taken to be that of uplift at the end of the Ketilidian metamorphism.

$$
1633 \pm 33 \mathrm{~m} . \mathrm{y} .
$$

226/32. Biotite-hornblende granite associated with appinitic-dioritic suite. Southeast corner of Otte Rud Øer. $62^{\circ} 05^{\prime} \mathrm{N}, 42^{\circ} 05^{\prime} \mathrm{W}$. R. Bøgvad, 1932

A recrystallised member of an appinite-diorite suite presumed to have been intruded at approximately the same time as $272 / 32$ above. The $\mathrm{K} / \mathrm{Ar}$ age is interpreted as that of uplift after the Ketilidian metamorphism in the area which affects all the intrusions. North of the area affected by Ketilidian metamorphism similar calc-alkaline rocks gave a K/Ar age of $2293 \mathrm{~m}$.y. (Bridgwater 1970); however it is not known whether there is more than one major period of late Archaean - early Proterozoic intrusion of this type in SE Greenland. 


$$
1634 \pm 33 \mathrm{~m} \text {. y. biotite }
$$

234/32. Hornblende-biotite gneiss, Napassorssuaq Fjord, $61^{\circ} 43^{\prime} \mathrm{N}, 42^{\circ} 19^{\prime} \mathrm{W}$.

R. Bøgvad, 1932

A moderately mafic gneiss from the north side of Napassorssuaq Fjord, one third of the way in. The gneisses in this area consist dominantly of intermediate and basic metavolcanic rocks similar to the volcanic rocks of Kobberminebugt on the southwest coast of Greenland (Watterson, 1965). The sample analysed, which consists of hornblende, biotite, plagioclase, microline and quartz with minor iron oxides, apatite and sphene, appears to be a normal member of this succession. The feldspar in the rock is clouded and there is some cataclasis suggesting that the rock had passed through a metamorphism after the original crystallisation of the main mineral assemblage. The age obtained is taken to be that of the local uplift at the end of the Ketilidian metamorphism in this area.

$$
1880 \pm 56 \mathrm{~m} . \mathrm{y} . \text { hornblende }
$$

GGU 99495. Appinitic sill, west side Uvtorsiutit tunuat. $62^{\circ} 32^{\prime} 30^{\prime \prime} \mathrm{N}, 42^{\circ} 20^{\prime} \mathrm{W}$.

Bridgwater \& Gormsen (1969)

An appinite sill, thought in the field to be completely unaffected by thermal events after its intrusion, but seen in thin section to show signs of recrystallisation. The appinitic suite cuts several generations of dolerites and metadolerites in the area, including the metadolerite dyke giving a K/Ar age of $1922 \mathrm{~m}$. y. (GGU 99497, Bridgwater, 1970). The sample dated consists of large abundant poikilitic hornblendes in a medium-grained matrix of amphibole, alkali feldspar and accessory pyroxene, quartz, apatite, epidote, oxides and calcite. Slight shearing is present and many of the minerals show a slight overall clouded appearance. The $\mathrm{K} / \mathrm{Ar}$ age can either be taken as close to the original intrusion of this rock (assuming that the alteration is essentially deuteric), or it can be taken to be due to subsequent events such as those affecting GGU 99497 above, and representing a Ketilidian thermal event in the area. At present the second hypothesis seems the more probable.

\section{$2374 \pm 46 \mathrm{~m} . \mathrm{y}$. biotite ( 2 determinations)}

GGU 99335. Amphibolitic margin to a pyribolitic layer in quartzo-feldspathic gneisses, Igdluluarssuk (Bernstorffs Isfjord). $63^{\circ} 38^{\prime} \mathrm{N}, 40^{\circ} 42^{\prime} 30^{\prime \prime} \mathrm{W}$.

Bridgwater \& Gormsen (1969)

A retrograde metamorphosed margin to a layer of granulite facies two-pyroxenegarnet amphibolite with minor pelitic units found as a concordant layer in amphibolite facies gneisses. The margin of the unit contains considerable biotite suggesting the introduction of potassium along the zone bordering the surrounding granitic gneisses. Many of the feldspars show slight sericitisation thought to be the result of slight metasomatism at some time after the main metamorphic events affecting this rock. The $\mathrm{K} / \mathrm{Ar}$ age given is taken to be that of the youngest metasomatic event seen. 
$2445 \pm 45 \mathrm{~m}$. y. biotite ( 2 determinations)

GGU 99458. Gneissose hornblende-biotite granodiorite, south side Qasingortûp kangertiva. $62^{\circ} 27^{\prime} 30^{\prime \prime} \mathrm{N}, 42^{\circ} 21^{\prime} \mathrm{W}$.

Bridgwater \& Gormsen (1969)

A well-foliated biotite-hornblende gneiss interpreted as a granodiorite intruded into high-grade supracrustal rocks. The sample contains biotite, hornblende, plagioclase, quartz, microcline, sphene, apatite and zircon. The quartz and feldspar show slight post-crystallisation strain and there is a slight alteration of the feldspar locally. The biotite and hornblende show a crude foliation. The age is interpreted as that of uplift at the end of Archaean metamorphism in the area. The northernmost effects of the Proterozoic (Ketilidian) metamorphism are clearly rather irregular. Samples from the south of Mogens Heinesen Fjord (see 234/32 etc. this report) consistently give Proterozoic K/Ar ages. Samples GGU 99495 and GGU 99497 taken respectively $5 \mathrm{~km}$ north and $12 \mathrm{~km}$ north-west of the present sample give younger ages also interpreted as the effects of Ketilidian metamorphism.

\section{$2497 \pm 80 \mathrm{~m}$. y. whole rock ( 2 determinations)}

GGU 99365. Granulite facies hypersthene-hornblende-plagioclase gneiss, Finnsbu. $63^{\circ} 22^{\prime} 40^{\prime \prime} \mathrm{N}, 41^{\circ} 18^{\prime} \mathrm{W}$.

Bridgwater \& Gormsen (1969)

A high-grade supracrustal sequence of basic and ultrabasic igneous rocks with minor pelitic units found as concordant units within amphibolite facies gneisses. This unit is cut by $160^{\circ}$ dolerite dykes (see GGU 99362, p. 57). The rock dated is generally fresh. There are some microfractures with haematite staining. The age obtained is taken to be a reasonable minimum age for the end of Archaean metamorphism in the area.

$$
\begin{gathered}
2688 \pm 54 \mathrm{~m} . \mathrm{y} . \text { hornblende } \\
2636 \pm 53 \mathrm{~m} . \text { y. biotite }
\end{gathered}
$$

GGU 99563. Hornblende-rich enclave in the Archaean gneisses, Igteqarajugtoq peninsula. $62^{\circ} 49^{\prime} \mathrm{N}, 42^{\circ} 24^{\prime} \mathrm{W}$.

Bridgwater \& Gormsen (1969)

A fresh hornblende-biotite-plagioclase rock forming an inclusion in granodioritic gneisses north-west of Tingmiarmiut. The basic enclaves in this area are thought to be relics of an old layered igneous complex. The K/Ar ages obtained are taken to mark the close of the main Archaean metamorphism in the area.

\section{References}

Andrews, J. R. \& Emeleus, C. H. 1971 : Preliminary account of kimberlite intrusions from the Frederikshåb district, South-West Greenland. Rapp. Gronlands geol. Unders. 31.

Bridgwater, D. 1970: A compilation of K/Ar age determinations on rocks from Greenland carried out in 1969. Rapp. Grønlands geol. Unders. 28, 47-55.

Bridgwater, D. \& Gormsen, K. 1969: Geological reconnaissance of the Precambrian rocks of SouthEast Greenland. Rapp. Gronlands geol. Unders. 19, 43-50.

Dawes, P. R. 1971: The North Greenland fold belt and environs. Bull. geol. Soc. Denmark 20, 197-239. 
Dawes, P. R. \& Soper, N. J. 1970: Geological investigations in northern Peary Land. Rapp. Grønlands geol. Unders. 28, 9-15.

Escher, A., Escher, J., \& Watterson, J. 1970: The Nagssugtoqidian boundary and the deformation of the Kângamiut dyke swarm in the Søndre Strømfjord area. Rapp. Grønlands geol. Unders. 28, 21-23.

Escher, A. \& Pulvertaft, T. C. R. 1968: The Precambrian rocks of the Upernavik-Kraulshavn area $\left(72^{\circ}-\right.$ $\left.74^{\circ} 15^{\prime} \mathrm{N}\right)$, West Greenland. Rapp. Gronlands geol. Unders. 15, 11-14.

Henriksen, N., \& Jepsen, H. F. 1970: K/Ar age determinations on dolerites from southern Peary Land. Rapp. Gronlands geol. Unders. 28, 55-58.

Keto, L. 1970: Isua, a major iron ore discovery in Greenland. Unpublished report from Kryolitselskabet Øresund A/S, Copenhagen.

Lambert, R. St. J. \& Simons, J. G. 1969: New K/Ar age determinations from southern West Greenland. Rapp. Gronlands geol. Unders. 19, 68-71.

Larsen, O. \& Møller, J. 1968: K/Ar age determinations from western Greenland I. Reconnaissance programme. Rapp. Gronlands geol. Unders. 15, 82-86.

Sarsadskikh, N. N., Blagul'kina, V. A. \& Silin, Yu. I. 1966: Absolute age of Yakutian kimberlites. Dokl. Acad. Sci. USSR, Earth Sci. Sect. 168, 48-50.

Watterson, J. 1965: Plutonic development of the Ilordleq area, South Greenland. Bull. Gronlands geol. Unders. 51 (also Meddr Grønland, 172, 7) 147 pp.

Wanless, R. K., Stevens, R. D. \& Loveridge, W. D. 1970: Anomalous parent-daughter isotopic relationships in rocks adjacent to the Grenville front near Chibougamau, Quebec. Eclog. geol. Helv. 63; 1, 345364.

Windley, B. F. 1970: Primary quartz ferro-dolerite/garnet amphibolite dykes in the Sukkertoppen region of West Greenland. In Newall, G. \& Rast, N. (editors) Mechanism of igneous intrusion, 79-92. Liverpool Geol. Soc.

\section{SIGNIFICANCE OF K/AR AGE DETERMINATIONS FROM NORTHERN PEARY LAND}

\section{Peter R. Dawes and N. J. Soper}

Following the 1969 field work in northern Peary Land (Dawes \& Soper, 1970) seven rocks were chosen for a preliminary age dating programme - two volcanics from the Kap Washington Group, four metasedimentary schists and a single sample from a cross-cutting E-W dolerite dyke. The details of these determinations are listed elsewhere in this report (see p. 53).

Northern Peary Land forms the eastern part of the North Greenland fold belt, which occupies the extreme northern coastal region as a roughly $\mathrm{E}-\mathrm{W}$ striking belt of deformation and metamorphism. The dated schists represent metamorphic Lower Palaeozoic sediments which form the bedrock in the extreme northern part of Peary Land. Farther south the Lower Palaeozoic sediments are non-metamorphic or only slightly metamorphosed. The sediments in northern Peary Land show a complex metamorphic and deformational history and they have been affected by 